\title{
Intraspecific mitochondrial DNA variation in the migratory grasshopper, Melanoplus sanguinipes
}

\author{
W. CHAPCO, R. A. KELLN* \& D. A. MCFADYEN† \\ Departments of Biology and *Chemistry, University of Regina, Regina, Saskatchewan, Canada, S4S OA2
}

\begin{abstract}
Restriction fragment analysis of mitochondrial DNA (mtDNA) was used to examine genetic variation and population structure of the migratory grasshopper, Melanoplus sanguinipes. The total DNA of 89 individuals was digested with 10 restriction enzymes and probed with three cloned EcoRI fragments representing the entire mitochondrial genome (total length $16.1 \mathrm{~kb}$ ). Five endonucleases revealed polymorphism, yielding 12 haplotypes in combination. Nucleotide diversity indices $(\delta)$ between haplotypes ranged from 0.18 to 0.92 per cent with an average value $(\pi)$ of 0.27 per cent, a comparatively low figure that possibly reflects a history of chronically small population numbers prior to the species' colonization of a suitable habitat engendered by agricultural settlement. Little, if any, differentiation was evident among locations or between prairie and parkland regions, areas spanned by a colour trait cline. Selective forces with respect to the latter must, therefore, be sufficiently powerful to withstand the attenuating effects of widespread gene flow, implied by the mtDNA data.
\end{abstract}

Keywords: grasshoppers, Melanoplus, mitochondrial DNA, population structure.

\section{Introduction}

The migratory grasshopper, Melanoplus sanguinipes, is widely distributed throughout North America, and, along with a few congeners, is regarded as a serious crop pest, especially in prairie and rangeland areas. A fundamental component of a successful pest management strategy is an appreciation of the genetic diversity and structure of targeted populations. Such information is generally lacking for most Orthopteran fauna but the situation is slowly changing, at least for $M$. sanguinipes (Chapco et al., 1987). Genetic analysis of the latter has revealed a number of heritable morphological and electrophoretic polymorphisms, for which an interesting dichotomy in spacial patterns appears to exist in the province of Saskatchewan. There is a prominent two-dimensional gradient between parkland (north-east) and prairie regions with respect to a hind tibia colour gene, contrasting with the fairly homogeneous allelic distributions of a number of allozyme

Correspondence: Dr W. Chapco, Department of Biology, University of Regina, Regina, Saskatchewan, Canada, S4S 0A2.

†Present address: Department of Genetics, University of Alberta, Edmonton, Alberta, Canada T6G 2E 1. loci (Chapco \& Bidochka, 1986). At one time, parkland and prairie populations were afforded subspecies status (Brooks, 1958) but the allozyme work would appear to confirm Vickery's (1979) suspicion that the claim is premature. Different relative strengths of gene flow and local adaptive values are possible explanations for the discrepancy in geographical distributions of the two types of traits (Chapco, 1989). A genetic marker that is ideally suited to address these and related issues is mitochondrial DNA (mtDNA). Owing to features such as maternal and non-recombinational transmission and a rapid rate of evolution (Harrison, 1989), the analysis of spatial and phylogenetic patterns associated with mtDNA has provided insights into populational structure and lineage as well as migrational and historical events for many organisms (Avise, et al., 1987). On the surface, it might be expected that the amount of interpopulational differentiation is minimal, especially for a species such as $M$. sanguinipes with its almost legendary reputation for migration and outbreak (Vickery \& Kevan, 1983; Pfadt, 1988). As the movement of organisms is not necessarily equivalent to gene flow (Endler, 1977), this prediction may not be realized although there is some evidence that 
migrating females do oviposit (Parker et al., 1955; McAnelly \& Rankin, 1986). In this paper, an analysis of restriction fragment length polymorphisms (RFLP) of grasshoppers obtained from several areas in southcentral Saskatchewan and from a few areas outside the province is presented with the view to addressing the aforementioned microevolutionary issues.

\section{Materials and methods}

A total of 89 adult grasshoppers, assayed for their mtDNA profiles, were sampled during 1989 and 1990 from 14 locations in south-central Saskatchewan and from five sites outside the province (Table 1). Interlocational distances in Saskatchewan range from 16 to $430 \mathrm{~km}$. Ontario and New Mexico sites are, on average, 2,700 and $2,000 \mathrm{~km}$, respectively from the main study area. A laboratory non-diapause strain of $M$. sanguinipes (Pickford \& Randell, 1969) provided material from which mtDNA probes were constructed.

\section{Isolation of mtDNA}

A modification of Tamura \& Aotsuka's (1988) rapid alkaline lysis method was used. Between 70 and 90 live adult grasshoppers from the non-diapause strain were gassed briefly with $\mathrm{CO}_{2}$ before being ground in a chilled mortar with acid-washed sea sand and homogenizing buffer $(0.25 \mathrm{~m}$ sucrose, $10 \mathrm{~mm}$ EDTA and $30 \mathrm{~mm}$ Tris- $\mathrm{HCl}, \mathrm{pH} 7.5$ ). Grinding was continued until there were no large tissue fragments remaining. The crude homogenate was centrifuged in a $50-\mathrm{ml}$ centrifuge tube at $1,100 \mathrm{~g}$ for $5 \mathrm{~min}$ at $4^{\circ} \mathrm{C}$ to remove the sand. The supernatant was then transferred to a second tube and centrifuged at $3,000 \mathrm{~g}$ for $5 \mathrm{~min}$ at $4^{\circ} \mathrm{C}$ in order to pellet nuclei and cellular debris. The soluble cell fractions containing the mitochondria were then pooled and centrifuged at $20,400 \mathrm{~g}$ for $20 \mathrm{~min}$ at $4^{\circ} \mathrm{C}$. The resulting mitochondrial pellet was resuspended in $1 \mathrm{ml}$ of lysis buffer $(0.15 \mathrm{M} \mathrm{NaCl}, 10 \mathrm{~mm}$ EDTA, $10 \mathrm{~mm}$ Tris- $\mathrm{HCl}, \mathrm{pH}$ 8.0). Two volumes of a freshly prepared

Table 1 Sampling locations and mtDNA haplotypes of Melanoplus sanguinipes

\begin{tabular}{|c|c|c|c|c|}
\hline Location & Latitude & Longitude & $\begin{array}{l}\text { Haplotype* } \\
\text { (number of individuals) }\end{array}$ & $n_{\dagger}^{\dagger}$ \\
\hline \multicolumn{5}{|l|}{ Saskatchewan } \\
\hline \multicolumn{5}{|l|}{ Prairies } \\
\hline Hanley & 51.4 & 106.3 & $1^{*}(2), 3(2), 4(1), 5(2), 6(1)$ & 8 \\
\hline Crestwynd & 50.1 & 105.1 & $1(2), 4(1), 5(1)$ & 4 \\
\hline Rowatt & 50.3 & 104.6 & $1(1), 3(1), 5(2)$ & 4 \\
\hline Parry & 49.5 & 104.5 & $1(2), 3(1), 5(2)$ & 4 \\
\hline Dilke & 50.5 & 105.1 & $1(1), 2(3)$ & 4 \\
\hline Avonlea & 50.0 & 105.0 & $1(2), 5(1)$ & 3 \\
\hline Chamberlain & 50.5 & 105.3 & $1(2), 3(2), 5(1)$ & 5 \\
\hline Lumsden & 50.3 & 104.5 & $1(1), 2(1), 5(5), 6(1), 11(1)$ & 9 \\
\hline Horizon & 49.3 & 105.1 & $7(2)$ & 7 \\
\hline Assiniboia & 49.6 & 106.0 & $7(2), 8(1)$ & 3 \\
\hline \multicolumn{5}{|l|}{ Parkland } \\
\hline Springside & 51.4 & 102.8 & $1(1), 9(1), 10(9)$ & 11 \\
\hline Balcarres & 50.5 & $103 \cdot 3$ & $1(1), 2(1), 3(1)$ & 3 \\
\hline Hudson Bay & 52.5 & 102.3 & $1(6), 10(3), 20(1)$ & 10 \\
\hline Kipling & 49.6 & 102.4 & $3(2), 5(3)$ & 5 \\
\hline \multicolumn{5}{|l|}{ Outside Saskatchewan } \\
\hline Mauston (Wisc) & 43.6 & 89.5 & $3(3)$ & 3 \\
\hline Alexandria (Minn) & 46.0 & 95.2 & $5(4)$ & 4 \\
\hline Turtle Lake (ND) & 47.3 & 100.8 & $1(1)$ & 1 \\
\hline Tobermory (Ont) & 45.3 & 81.7 & $5(2)$ & 2 \\
\hline Santa Fe (NM) & 35.1 & 106.0 & $3(2), 4(2)$ & 4 \\
\hline
\end{tabular}

*Haplotypes: 1 = AAAAAAAAAA, 2 = AAAAAAABAA,

$3=\mathrm{ABAAAAABAA}, 4=$ ABAAAADBAA, $5=$ ABAAAAAAAA,

$6=\mathrm{ABAAAADAAA}, 7=\mathrm{ABAABAABAA}, 8=\mathrm{AAAABAAAAA}$

$9=$ ABAAAAGAAA, 10=AAAAAADAAA, $11=$ AAAAAADBAA,

$20=$ BAAAAAAAAA. Letters refer to genotypes of restriction enzymes listed in the same order as presented in Table 2. †Sample size. 
solution of 1 per cent SDS in $0.2 \mathrm{M} \mathrm{NaOH}$ were added, and the mixture was vortexed briefly. Following storage on ice for $5 \mathrm{~min}, 1.5 \mathrm{ml}$ of ice cold $3.0 \mathrm{~m}$ sodium acetate ( $\mathrm{pH} 4.8$ ) was added and the mixture was again gently vortexed before storing on ice for an additional $10 \mathrm{~min}$. The mixture was then centrifuged at $20,400 \mathrm{~g}$ for 15 $\min$ at $4^{\circ} \mathrm{C}$. The supernatant was removed and extracted with an equal volume of phenol-chloroform (one part Tris- $\mathrm{HCl}$ buffered phenol, $\mathrm{pH} 8.0$ and one part chloroform:isoamyl alcohol, 24:1), and centrifuged at $14,600 \mathrm{~g}$ for $5 \mathrm{~min}$ at room temperature. mtDNA was precipitated from the aqueous phase by the addition of two volumes of 95 per cent ethanol. The tube was allowed to stand at room temperature for at least $15 \mathrm{~min}$ before being centrifuged at $20,400 \mathrm{~g}$ for $15 \mathrm{~min}$ at room temperature. The resulting mtDNA pellet was washed twice with $3 \mathrm{ml}$ of 70 per cent ethanol before being dried in vacuo.

The dried mtDNA pellets were dissolved in $6 \mathrm{ml}$ of $10 \mathrm{~mm}$ Tris- $\mathrm{HCl}, 1 \mathrm{~mm}$ EDTA, $\mathrm{pH} 8.0$, to which was added $6 \mathrm{~g} \mathrm{CsCl}$ and $600 \mu \mathrm{l}$ of ethidium bromide $(5 \mathrm{mg}$ $\left.\mathrm{ml}^{-1}\right)$. The solution was mixed and left at room temperature for $30 \mathrm{~min}$ and then centrifuged at $7,700 \mathrm{~g}$ for $10 \mathrm{~min}$ at room temperature. The supernatant was transferred to a centrifuge tube (Quick-Seal G-Max centrifuge tube, Beckman Instruments, Inc., Palo Alto, CA) sealed and centrifuged at $48,000 \mathrm{rpm}$ for $20 \mathrm{~h}$ at $25^{\circ} \mathrm{C}$ in a Ti 80 rotor. A band (the lowermost) corresponding to covalently closed circular mtDNA was visualized under long-wave ultraviolet light and withdrawn by puncturing the tube from the side with an 18gauge needle attached to a $1-\mathrm{ml}$ syringe. Ethidium bromide was extracted with $n$-butanol saturated with $4 \mathrm{M} \mathrm{NaCl}, 10 \mathrm{~mm}$ Tris- $\mathrm{HCl}$ and $1 \mathrm{~mm}$ EDTA, $\mathrm{pH}$ 8.0. After dialysing for $16 \mathrm{~h}$ against two changes of dialysis buffer $(4 \mathrm{~mm} \mathrm{NaCl}, 1 \mathrm{~mm}$ EDTA and $10 \mathrm{~mm}$ Tris- $\mathrm{HCl}$, $\mathrm{pH} 8.0$ ), the purified mtDNA was stored at $4^{\circ} \mathrm{C}$.

\section{Isolation of total genomic DNA}

Total genomic DNA was isolated from individual grasshoppers according to the method of Marchant (1988) with minor modifications.

\section{Cloning of $\mathrm{M}$. sanguinipes $m t D N A$}

In general, the procedures described by Maniatis et al. (1982) were followed with respect to standard recombinant DNA techniques such as large-scale isolation of plasmid DNA, CsCl gradient centrifugation, the rapid alkaline lysis method for isolation of plasmid DNA, restriction endonuclease digestion of DNA, agarose gel electrophoresis of nucleic acids, transformation of Escherichia coli by the calcium chloride method, liga- tion reactions, dephosphorylation of linearized vectors and isolation of restriction fragments from agarose gels using a commercial electroeluter (International Biotechnologies Inc., New Haven, CT). Hexamine cobalt chloride was included in ligation reaction mixes at a final concentration of $1.2 \mathrm{~mm}$ (Rusche \& HowardFlanders, 1985).

Purified mtDNA from the non-diapause laboratory strain of $M$. sanguinipes was digested to completion with $E c o$ RI according to the supplier's recommendations. The EcoRI-digested mtDNA was ligated to CIPdephosphorylated, EcoRI-cleaved pUC18 vector DNA. Recombinant plasmids were selected in $E$. coli strain $\mathrm{JM} 83 \mathrm{r}^{-}$using the culture conditions and screening methods described in Maniatis et al. (1982). Insertion of specific mtDNA fragments into the vector was confirmed by isolation of the plasmid DNA and assessing the EcoRI restriction pattern.

\section{Restriction endonuclease digestion of total DNA}

Total DNA from individual grasshoppers was separately digested with 10 restriction endonucleases (Bethesda Research Laboratories or New England Biolabs): AccI, AluI, BglII, DraI, EcoRI, HinfI, HpaI, PstI, PvuII, and $X b a \mathrm{I}$. All digests were carried out in $100-\mu l$ volumes in reaction conditions as specified by the supplier. Following digestion, the DNA was precipitated directly by the addition of 2.5 volumes of 95 per cent ethanol at $-20^{\circ} \mathrm{C}$. DNA pellets were collected by microcentrifugation for $15 \mathrm{~min}$, dried in in vacuo and resuspended in $15 \mu \mathrm{l}$ of $10 \mathrm{~mm}$ Tris- $\mathrm{HCl}, 1 \mathrm{~mm}$ EDTA, $\mathrm{pH} 8.0$ and then electrophoresed in 1 or 1.2 per cent agarose gels.

\section{Southern transfer procedures}

Gels containing the digested total DNA were sequentially treated ( $30 \mathrm{~min}$ each) with depurination solution $(0.25 \mathrm{M} \mathrm{HCl})$, denaturation solution $(0.6 \mathrm{M} \mathrm{NaCl}, 0.2 \mathrm{M}$ $\mathrm{NaOH})$ and neutralization solution $(1.5 \mathrm{M} \mathrm{NaCl}, 0.5 \mathrm{M}$ Tris- $\mathrm{HCl}, \mathrm{pH} 7.0$ ) with constant shaking.

Capillary transfers to nylon membranes (Hybond-N, Amersham) were set up according to Southern (1975). In certain cases double membrane capillary transfers were obtained from the same gel. Conditions were essentially the same as those used for single transfers except that gels were sandwiched between two nylon membranes.

Gels were stained with ethidium bromide to determine whether any DNA remained untransferred. Membranes were then rinsed in $2 \times \mathrm{SSC}$ and the bound DNA was crosslinked with an ultraviolet lamp (Stratalinker UV Crosslinker 1800, Stratagene, La Jolla, CA) 
set to release $120,000 \mu \mathrm{J}$. Once crosslinked, the membranes were wrapped in Saran Wrap and stored at room temperature.

\section{Radioactive labelling of probe DNA}

Recombinant plasmids pDM1, pDM2 and pDM3 (see Results) collectively containing the entire mitochondrial genome of $M$. sanguinipes were individually digested to completion with EcoRI. The DNA was then precipitated with 95 per cent ethanol, dried in vacuo and redissolved in $10 \mathrm{~mm}$ Tris- $\mathrm{HCl}, 1 \mathrm{~mm}$ EDTA, pH 8.0. Between 100 and $200 \mathrm{ng}$ of the digested plasmid DNA were used in separate random primer labelling reactions according to the method of Feinberg \& Vogelstein (1983 and 1984). In general, the activity of the probes was of the order of $1.0 \times 10^{7}$ c.p.m. $\mu \mathrm{g}^{-1}$. A mix containing approximately $1.0 \times 10^{6}$ c.p.m. from each random primer reaction was used for hybridization.

\section{Hybridization}

A hybridization oven (Model 310 Hybridization Incubator, Robbins Scientific Inc., Sunnyvale, CA) was used. Prehybridization, hybridization and wash conditions were essentially those described in the GeneScreenPlus ${ }^{\mathrm{TM}}$ instruction booklet provided by the supplier (Dupont/NEN). Membranes were washed with two changes of $2 \times \mathrm{SSC}, 1$ per cent SDS for 30 min at $65^{\circ} \mathrm{C}$. A final wash with two changes of $0.1 \times \mathrm{SSC}$ for $20 \mathrm{~min}$ at room temperature was used to remove excess SDS.

\section{Data analysis}

Restriction enzyme fragment profiles were designated as a sequence of 10 upper-case letters AAAAAAAAAA, BAAAAAAAAA, etc. where each letter refers to a particular banding 'morph' of EcoRI, BglII, Pst I, $A c c \mathrm{I}, P v u \mathrm{II}, X b a \mathrm{I}, H i n f \mathrm{l}, H p a \mathrm{I}, A l u \mathrm{I}$, and Dral, respectively. Estimates of nucleotide sequence divergence, $\delta$, based on the proportion of shared fragments, were obtained for all pairs of haplotypes according to equations 20 and 21 in Nei \& Li (1979). Separate values were determined for the different classes of endonucleases and weighted according to the number of fragments revealed. Values were then used to construct a dendrogram by the unweighted pair-group method (UPGMA) employing the SPSS-X (Release 3) program, CLUSTER. A measure of the overall diversity for the species was provided by the nucleotide diversity index $\pi$ (Nei, 1987) which takes into account frequencies of haplotypes.
Haplotypes were also converted into strings of $1 \mathrm{~s}$ and $0 \mathrm{~s}$ for a cladistic analysis using the parsimony criterion. The Phylip program, METro provided by J. Felsenstein (1988) was used. For most enzymes exhibiting variation, the connection between one array of fragments (designated as ' 0 ') and another (designated '1') was easily visualized and required a single site change. No simple set of transformations connecting the various patterns was evident for the exception, $H i n-f l$. In this case, $1 \mathrm{~s}$ and $0 \mathrm{~s}$ were used to indicate the presence or absence of specific bands.

\section{Results}

Three EcoRI fragments of 8.0, 6.8 and $1.2 \mathrm{~kb}$ were cloned into pUC18 to yield recombinant plasmids pDM1, pDM2 and pDM3, respectively. When these were used collectively to probe the total DNA from individual insects, an average of about 44 scorable fragments were obtained per insect; fragment patterns and sizes are recorded in Table 2. AluI, DraI, and Hinfl produced the greatest number of bands, many of small size. As the sums of these lengths are comparatively low, it is likely that even smaller pieces were undetected. It is also possible that some bands are really collections of two or more DNA fragments of equal (or near-equal) mobilities. Totals of fragment sizes for the remaining enzymes (average

Table 2 Restriction fragment patterns and sizes (bp)

\begin{tabular}{|c|c|c|}
\hline Enzyme & Pattern & Fragment sizes \\
\hline \multirow[t]{2}{*}{ EcoRI } & A & $8000,6800,1200$ \\
\hline & $\mathbf{B}$ & $8000,3800,3000,1200$ \\
\hline \multirow[t]{2}{*}{$B g l I I$} & A & $6800,5600,2400,1200$ \\
\hline & B & $6800,1200,7800$ \\
\hline Pst I & A & 16300 \\
\hline$A c c \mathrm{I}$ & A & $8800,4800,2600$ \\
\hline \multirow[t]{2}{*}{$P v u \mathrm{II}$} & A & 13400,2600 \\
\hline & $\mathbf{B}$ & 16300 \\
\hline$X b a \mathbf{I}$ & A & $7300,4400,2100,1600,600$ \\
\hline \multirow[t]{3}{*}{ HinfI } & A & $\begin{array}{l}3700,2600,1200,700,600 \\
\quad 500,450\end{array}$ \\
\hline & D & $\begin{array}{l}3700,2600,1200,900,700 \\
\quad 600,500,450,400\end{array}$ \\
\hline & $\mathrm{G}$ & $\begin{array}{l}2600,1200,900,700,600 \\
\quad 550,450,400\end{array}$ \\
\hline \multirow[t]{2}{*}{ HpaI } & A & $13300,1700,1000$ \\
\hline & B & 15000,1000 \\
\hline DraI & A & $\begin{array}{l}1750,1600,1250,1000,850 \\
\quad 700,575,400\end{array}$ \\
\hline AluI & A & $\begin{array}{l}2100,1300,900,800,700 \\
\quad 600,450,400,375\end{array}$ \\
\hline
\end{tabular}


value $=16.1 \pm 0.2 \mathrm{~kb}$ ) were in close agreement with the sum of sizes for the cloned EcoRI pieces; it is therefore probable that this figure is a reasonable estimate of the size of the mitochondrial genome for $M$. sanguinipes.

All individuals exhibited the same patterns for Pst $\mathrm{I}$, $A c c \mathrm{I}, X b a \mathrm{I}, D r a \mathrm{I}$ and $A l u \mathrm{I}$. Two to three variant patterns were observed for each of the five remaining endonucleases. For EcoRI, BglII, PvuII, and HpaI different morphs were separable by a single loss or gain of a restriction site. Variants with respect to Hinfl, require at least two site changes to interconvert one to another. In total, 12 different composite genotypes (haplotypes) were detected among the 89 grasshoppers representing 19 locations (Table 1). Haplotypes 1, 3 and 5 accounted for about 75 per cent of the samples and were broadly distributed throughout the study area. Their relative frequencies were not significantly different between prairie and parkland areas $(4 \times 2$ contingency $G=1.67, P<0.65)$. Among the remaining genotypes, four were unique. Most haplotypes that were detected in at least two individuals were present in more than one location; in some cases, sites were far apart - e.g. haplotype 2 (Dilke and Balcarres) or proximal - e.g. haplotype 7 (Assiniboia and Horizon). Three grasshoppers in Hudson Bay possessed genotype 10 , not found elsewhere. All genotypes detected outside the province also occurred in Saskatchewan. For example, of the four insects collected in Santa Fe, New Mexico, two were haplotype 3 and two were haplotype 4; grasshoppers exhibiting pattern 5 were also found in Ontario and Minnesota.

Nucleotide divergence estimates ( $\delta$ in Table 3 ) between pairs of haplotypes ranged from 0.178 per cent ( 1 vs. 10,5 vs. 6,2 vs. 11 and 3 vs. 4 ) to 0.920 per cent ( 7 vs. 9). For Saskatchewan, the average nucleotide diversity (taking into account haplotype frequencies) was 0.265 per cent. Thirteen of 14 sites in the province were polymorphic for two or more haplotypes. Many of the latter, where they co-occur, differ by one to three restriction site changes. Crestwynd contains haplotypes 1 and 4 , which differ by at least four sites taking into account the uncertainty regarding Hinfl. Within collection site nucleotide diversity ranged from 0 (Horizon) to 0.33 per cent (Crestwynd) with an average value of 0.194 per cent, a figure that is about 72.9 per cent of the variation among haplotypes, ignoring population structure. This translates into an interpopulational nucleotide diversity index $\tau_{\mathrm{ST}}(\mathrm{Nei}, 1982)$ of 27.1 per cent, signifying very little differentiation among sampled sites. The extent of differentiation between prairie and parkland regions can similarly be evaluated. The average diversity within each region is 0.256 per cent, not much different than that for the entire area when treated as a panmictic unit. There is, therefore, very little divergence $\left(\tau_{\mathrm{ST}}=3.6\right.$ per cent) between prairie and parkland areas; this agrees with the haplotype frequency analysis presented earlier.

The UPGMA dendrogram employing interhaplotype $\delta$ values is displayed in Fig. 1. Clustered together are haplotypes 3 with 4,5 with 6,2 with 11 , and 1 with 10 . Members of each pair differ with respect to HinfI cleavage sites by at least two mutational differences (A vs. D). At a higher level, there appear to be two main clusters: (3-7) and $(2,11,1,10,20,8)$, separated on the basis of BglII. Haplotype 9, distinguished by the Hinfl pattern, G, is separated from the rest. No association between the dendrogram and geographical distribution is evident. Locations involving larger sample sizes are represented by members of both major clusters.

Repeated application of the cladistics program METRO yields a myriad of equally parsimonious Wagner

Table 3 Percentage divergence $(\delta)$ between mtDNA haplotypes based on proportion of shared restriction fragments $(\mathrm{Nei} \& \mathrm{Li}$, 1979)

\begin{tabular}{|c|c|c|c|c|c|c|c|c|c|c|c|}
\hline Haplotype & 20 & 5 & 2 & 10 & 8 & 3 & 6 & 11 & 7 & 9 & 4 \\
\hline 1 & 0.190 & 0.197 & 0.197 & 0.178 & 0.197 & 0.420 & 0.375 & 0.375 & 0.671 & 0.678 & 0.598 \\
\hline 20 & & 0.403 & 0.403 & 0.367 & 0.403 & 0.641 & 0.580 & 0.580 & 0.912 & 0.883 & 0.819 \\
\hline 5 & & & 0.420 & 0.375 & 0.420 & 0.206 & 0.178 & 0.598 & 0.439 & 0.480 & 0.383 \\
\hline 2 & & & & 0.375 & 0.420 & 0.206 & 0.598 & 0.178 & 0.439 & 0.901 & 0.383 \\
\hline 10 & & & & & 0.375 & 0.598 & 0.197 & 0.197 & 0.849 & 0.462 & 0.420 \\
\hline 8 & & & & & & 0.671 & 0.598 & 0.598 & 0.439 & 0.901 & 0.849 \\
\hline 3 & & & & & & & 0.383 & 0.383 & 0.216 & 0.686 & 0.178 \\
\hline 6 & & & & & & & & 0.420 & 0.617 & 0.265 & 0.206 \\
\hline 11 & & & & & & & & & 0.617 & 0.685 & 0.206 \\
\hline 7 & & & & & & & & & & 0.920 & 0.393 \\
\hline 9 & & & & & & & & & & & 0.471 \\
\hline
\end{tabular}




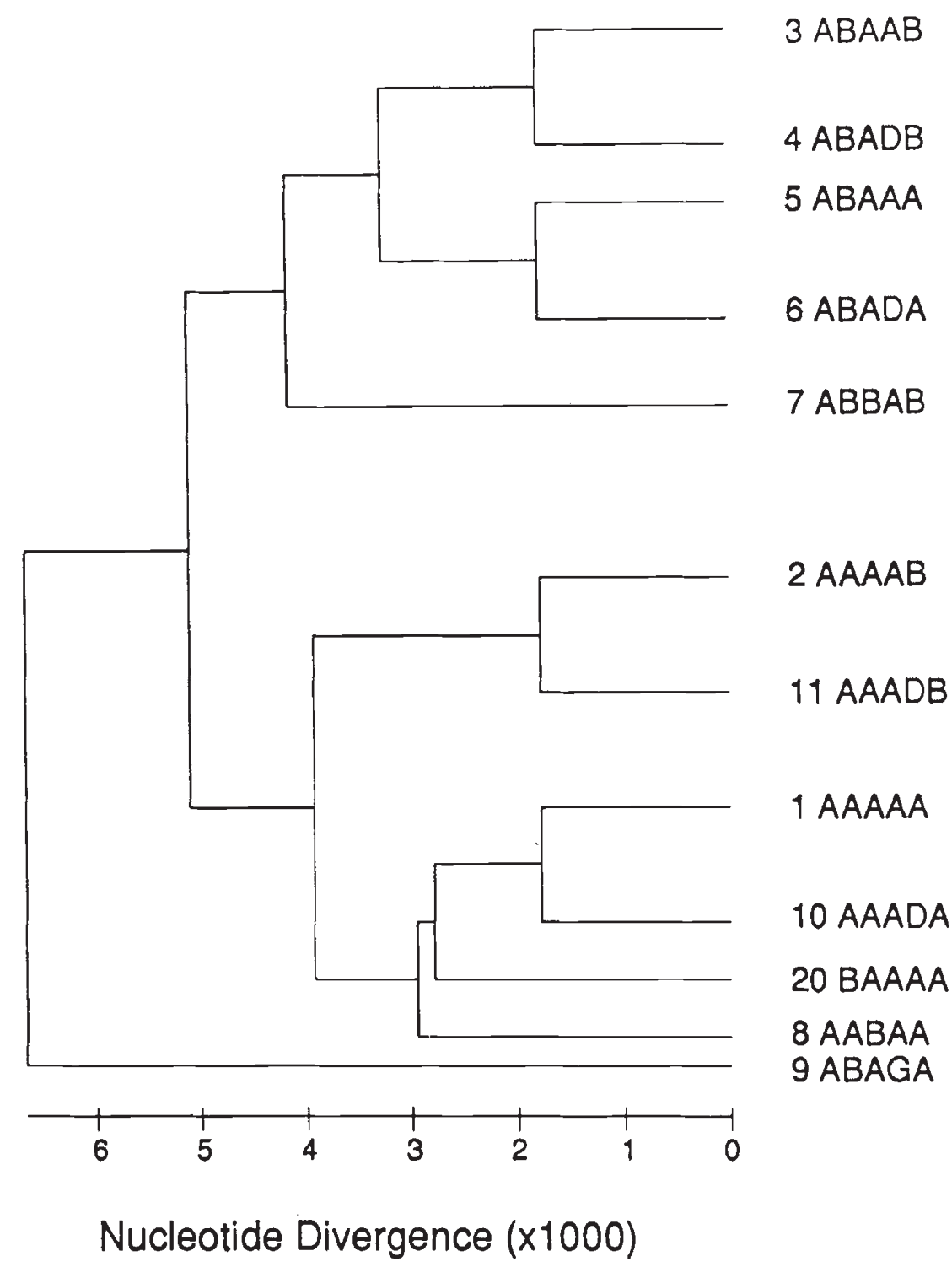

Fig. 1 Dendrogram of mtDNA haplotypes assayed in Melanoplus sanguinipes based on UPGMA analysis of nucleotide divergence estimates $(\delta \times 1,000)$. Letters refer to polymorphic genotypes of restriction enzymes listed in the same order as presented in Table 1. networks each with 14 mutational steps. Most differ in the placement of minor types usually involving HinfI variants. Omitting HinfI results in four equally parsimonious trees, each with six steps. To varying extents they resemble the dendrogram. One in particular is a good match if it is assumed that: (i) haplotype 5 , the most frequent and widespread, is ancestral (Avise et al., 1987; Excoffier, 1990); (ii) parallel losses of restriction sites are more likely than parallel gains (Templeton, 1983); and (iii) common haplotypes that differ by a single restriction site are more likely to be directly connected rather than remotely linked via rarer intermediates. In this particular cladogram, haplotypes $(1,10)$ constitute a hub for haplotype $8,(2$, $11), 20$ and $(5,6,9)$. The latter group links directly with $(3,4)$ which in turn connects with 7 .

\section{Discussion}

The estimated length of the mitochondrial genome of Melanoplus sanguinipes is approximately $16.1 \mathrm{~kb}$, typical of most metazoans, including insects (Table 4). It is slightly larger than the mitochondrial genomes of the two acridids thus far analysed, Locusta migratoria and Caledia captiva. In other Orthopterans, individuals of two gryllid species are heteroplasmic for two of three size classes of mtDNA (Harrison et al., 1985), apparently not an uncommon phenomenon in invertebrates (Boyce et al., 1989). Within the limits of resolution in the present study, however, there were no arrays of banding patterns which would have suggested that individual grasshoppers possessed more than one 'type' of mtDNA. 
Table 4 Mitochondrial DNA sizes and intraspecific diversity estimates for diverse insects

\begin{tabular}{llcll}
\hline Order & Species & Size $(\mathrm{kb})$ & Diversity* & Source† \\
\hline \multirow{2}{*}{ Orthoptera } & Locusta migratoria & 15.2 & - & 1 \\
& Caledia captiva & 15.0 & - & 2 \\
& Gryllus pennsylvanicus \& & & & \\
& $\quad$ G. firmus & $15.8-16.4$ & - & 3 \\
\multirow{5}{*}{ Diptera } & Melanoplus sanguinipes & 16.1 & 0.27 & 4 \\
& Drosophila spp. & $15.5-18.7$ & $0.0-4.9$ & $5-8$ \\
& Anopheles albopictus & 17.5 & very low $\neq$ & 9 \\
& A. quadrimaculatus & 15.3 & - & 10 \\
& Glossina morsitans & - & $2.0-11.1$ & 11 \\
Hymenoptera & Cochliomyia hominovorax & 16.0 & 1.1 & 12 \\
& Apis mellifera & 17.0 & $0.33-4.1$ & 13 \\
& Dolichovespula spp. \& & & & \\
Coleoptera & $\quad$ Vespula spp. & $18.0-22.7$ & - & 14 \\
& Anthonomus grandis & 19.0 & - & 15 \\
& Pissodes spp. & $>30.0$ & - & 16 \\
Homoptera & Diabrotica decimapunctata & 21.0 & - & 12 \\
& Schizaphis graminum & - & $0.17-1.2$ & 17 \\
& Magicicada spp. & $19.6-20.0$ & $0.01-0.12$ & 18 \\
\hline
\end{tabular}

*Diversities estimated in various ways. Consult sources. Includes within- and between-racial, subspecific or biotype estimates.

†Sources: 1. McCracken et al. (1987), 2. Marchant (1988), 3. Harrison et al.(1985), 4. This study, 5. Gonzalez et al. (1990), 6. Hale \& Singh (1987), 7. Baba-Aïssa et al. (1988), 8. DeSalle et al. (1986), 9. Kambhampati \& Rai (1991), 10. Cockburn et al. (1990), 11. Trick \& Dover (1984), 12. Roehrdanz \& Johnson (1988), 13. Hall \& Muralidharan (1989), 14. Schmitz \& Moritz (1990), 15. Roehrdanz (1990), 16. Boyce et al. (1989), 17. Powers et al. (1989), 18. Martin \& Simon (1990).

$\ddagger$ Proportion of shared fragments, $F>0.99$.

The extent of mtDNA variation $(\pi=0.265$ per cent $)$ in $M$. sanguinipes falls within the lower range of published intraspecific nucleotide diversity values for insects (Table 4) and other taxa (see summaries in Martin \& Simon, 1990 and Becker et al., 1988). The average index is dominated by a low $\delta$ value $(0.020$ per cent) between the two most common genotypes, 1 and 5 , which differ from one another by a gain or loss of one restriction site. The third most frequent genotype (3) differs from these by two $(\delta=0.420$ per cent $)$ and one $(\delta=0.206$ per cent $)$ site $(s)$, respectively, and also makes a large contribution to the overall low diversity. Many theoretical arguments (Martin \& Simon, 1990) have been proposed to account for observed low levels of variation such as those based on purifying selection and low mutation rate. One of the more probable and satisfying explanations centres on the organism's biology and demographic past. Given $M$. sanguinipes' reproductive capacity (Pfadt \& Smith, 1972) and preference for fields disturbed by human activities (Pfadt, 1988), and given historical accounts (see refer- ences in Chapco \& Bidochka, 1986), it is reasonable to regard this insect as a recent 'colonist' of the area.

The availability of pod laying sites and introduced weeds and crops, which resulted from settlement, converted a previously innocuous and patchily distributed species to one of the major grasshopper pests on the prairies (Beirne, 1972). The situation seems to parallel Wilson et al's (1985) depiction of a population experiencing a prolonged bottleneck before expanding its numbers. The similarity is not quite exact in that there have been, at irregular intervals, population crashes as well as outbreaks in this century (Riegert, 1968). In any case, such populations are expected to exhibit low mtDNA diversity and, owing to chronically low numbers in the pre-agricultural past, low nuclear diversities. From the present study, this is clearly true for mtDNA, and from a previous investigation of isozymic variation, true for nuclear genes as well (Chapco \& Bidochka, 1986). Based on neutral theory (Nei, 1987 ) and the assumption of an evolutionary rate of 0.01 substitutions/base pair/lineage/million years (see 
below), a nucleotide diversity value of 0.265 per cent corresponds to an effective population size of $N_{\mathrm{c}}=133,000$. This index encapsulates previous historical events in that it is strongly influenced by small population sizes in the past. For reasons already stated, the latter were probably not large; moreover, additional depletions in population numbers must have occurred during various glaciation episodes, the last being about 15,000 years ago (Storer, 1989). Unfortunately, census records, in Saskatchewan at least, are poor prior to 1930 (Riegert, 1968). Nineteenth century accounts (see for example Smith, 1954 and Reigert, 1968) record, in qualitative terms, population sizes either for 'grasshoppers' in general of for $M$. spretus, the Rocky Mountain grasshopper, the major economic pest at that time. A conservative estimate of current population size in Saskatchewan can be obtained by multiplying a population density of three adults $\mathrm{m}^{-2}$ determined during non-outbreak years (Pfadt, 1988) by 16 million hectares, an estimated area of cultivated land for the province (Harris, 1987); this yields a 'guesstimate' of several billion insects. Despite the fact that $M$. sanguinipes is probably not uniformly distributed or that populations are not confined by political boundaries, it is safe to claim that the ratio of contemporary population size to $N_{\mathrm{c}}$ is astronomical, far greater than ratios estimated for vertebrates displaying similar low diversities and population structure (Avise et al., 1988).

With respect to effective population size, note that, according to Pickford \& Gillott (1972), mating preferences do occur in both sexes with some individuals coupling more frequently than others, some not at all. To the extent that these factors influence the number of reproducing offspring (mating frequency does influence fecundity - see Pickford \& Gillott, 1972), the net result would be to increase the variance of family size, which in turn is expected to lower $N_{\mathrm{e}}$ (Nei, 1987).

The present mtDNA findings have implications for $M$. sanguinipes' population genetics. Many of the larger intraspecific diversity values in the literature (Table 4) are associated with differences between biotypes, races or subspecies, usually separated geographically; within locational variation, where estimated, is low. For example, the major portion of nucleotide diversity (1.97 per cent) within Drosophila simulans is ascribed to differences among three (generally) spacially isolated cytoplasmic races; only 0 to 0.046 per cent variation exists within each cytotype (Baba-Aïssa et al., 1988). Non-Drosophila examples are Schizaphis graminum (Powers et al., 1989) and Glossina morsitans (Trick \& Dover, 1984). An intermediate example (Afonso et al., 1990) is provided by $D$. subobscura in which 61.2 per cent of the mtDNA diversity $(\pi=0.8$ per cent) is accounted for by population structure, with some locations possessing a fair amount of polymorphism (maximum $\pi=0.47$ per cent in one case). At the other extreme, most ( 74.3 per cent) of the variation in $D$. albomicans $(1.0$ per cent $)$ is represented by local polymorphism (Chang et al., 1989), a situation not unlike that for $M$. sanguinipes. Some combination of an organism's historical past (see below) and gene flow could conceivably account for limited differentiation among sampled locations. Thus, if extant populations of $M$. sanguinipes are descendants of a polymorphic population that occupied a single refugium about 15,000 years ago (see below), the amount of inter-site divergence engendered up to the present would not be detectably large. This is expected to be true even in the unlikely event of no gene flow post-glacial colonization. Given the widespread occurrence of common haplotypes in Ontario and New Mexico, it seems more likely that present-day populations stemmed from more than one refugium. If ancestors occupying these regions were already genetically diverse, the present phylogeographic continuities could only be explained by gene flow. Parallel examples of organisms which lack population structure owing to recency of colonization and/ or gene flow are marine fish (Becker et al., 1988) and red-winged blackbirds (Ball et al., 1988). Widespread panmixia should not, however, be automatically inferred on the basis of a perception of boundless movement as the biology of these organisms, including grasshoppers (Vickery \& Kevan, 1983; Pfadt, 1988), would suggest. This point is nicely illustrated by studies of the cosmopolitan D. melanogaster, a species often regarded as a 'high migration' insect but for which populations are significantly differentiated for a variety of traits including mtDNA (Hale \& Singh, 1987).

In the light of the above, the occurrence of clinal variation in hind tibia colour frequency in the region (Chapco \& Bidochka, 1986) is all the more significant. Grasshoppers in parkland areas are predominantly red-legged, whereas they are predominantly bluelegged on the prairies. The cline is at least 25 years old; selective agents are unknown (Chapco \& Bidochka, 1986). The absence of mtDNA differentiation between these two regions suggests that these forces must be sufficiently powerful to withstand the attenuating effects of gene flow.

Gurney \& Brooks (1959) recognize three subspecies of $M$. sanguinipes. Of these, two are represented in this paper: $M$. s. sanguinipes, which occur in Canada and the northern United States, and $M$. s. defectus, which are found in the southwestern United States. M. s. defectus is somewhat larger than $M$. s. sanguinipes (Chapco, 1987). They interbreed freely under laboratory conditions to produce viable and fertile descend- 
ants (Chapco, 1991). Haplotypes 3 and 4 are equally represented in the small New Mexico sample; both occur in Saskatchewan with haplotype 3 being the third most frequent. Further sampling is required to assess whether subspecies status is warranted. At one time (Brooks, 1958), prairie and parkland populations were regarded as possible subspecies but, as already indicated, there is very little difference between the two regions. The most northern site, Hudson Bay, possesses two haplotypes not found elsewhere. This location and more northern areas require further investigation.

To obtain a crude historical perspective of this insect, it may be useful to speculate on when pairs of haplotypes last shared a common (female) ancestor. The only insect for which evolutionary rates of substitution are available is Drosophila; values range from 0.12 to 3.13 per cent substitutions/base pair/lineage/ million years (Solignac et al., 1986). Based on the conventionally used rate of 1.0 per cent (Wilson et al., 1985), which falls within this range, two randomly chosen haplotypes last shared a common ancestor about 133 thousand years ago. The two most similar and most dissimilar haplotypes last shared a common ancestor 89 thousand and 460 thousand years ago, respectively. Prior to deglaciation in Saskatchewan 10 to 17 thousand years ago, it is likely that $M$. sanguinipes, or its ancestor, occupied local (e.g Wood Mountain and Cypress Hills) or distant (e.g. Beringia or vast areas south of the ice shield; see Vickery, 1989) refugia, expanding into Saskatchewan only after prairie replaced Black Spruce forest which had perfused the area after deglaciation (Storer, 1989). Acknowledging the uncertainties that accompany such calculations (e.g. evolutionary rates, $\delta$ estimates, etc.), it is, nonetheless, probable that populations were already polymorphic or genetically differentiated with respect to two or more haplotypes before colonization and, possibly, before the last ice age.

\section{Acknowledgements}

This work was supported by grants from the Natural Sciences and Engineering Research Council of Canada to WC and RAK Financial assistance from the Faculty of Graduate Studies and Research, University of Regina, to DAM is gratefully acknowledged. We thank E. J. Chapco for comments on the manuscript.

\section{References}

AFONSO, J. M., VOLZ, A., HERNANDEZ, M., RUTTKAY, H., GONZALEZ, M., LARRUGA, J. M., CABRERA, V. M. AND SPERLiCH, D. 1990. Mitochondrial DNA variation and genetic structure in oldworld populations of Drosophila subobscura. Mol. Biol.
Evol., 7, 123-142.

AVISE, J. C., ARNOLD, J., BALL, R. M., BERMINGHAM, E., LAMB, T., NEIGEL, J., REEB, C. A. AND SAUNDERS, N. C. 1987. Intraspecific phylogeography: The mitochondrial DNA bridge between population genetics and systematics. Annu. Rev. Ecol. Syst., 18, 489-522.

AVISE, J. C., BALL, R. M. AND ARNOLD, J. 1988. Current versus historical population sizes in vertebrate species with high gene flow: A comparison based on mitochondrial DNA lineages and inbreeding theory for neutral mutations. Mol. Biol. Evol., 5, 331-344.

BABA-AIISSA, F., SOLIGNAC, M., DENNEBOUY, N. AND DAVID, J. R. 1988. Mitochondrial DNA variability in Drosophila simulans: quasi absence of polymorphism within each of the three cytoplasmic races. Heredity, 61, 419-426.

BALL, R. M., FREEMAN, S., JAMES, F. C., BERMINGHAM, E. AND AVISE, J. C. 1988. Phylogeographic population structure of redwinged blackbirds assessed by mitochondrial DNA. Proc. Natl. Acad. Sci., U.S.A., 85, 1558-1562.

BECKER, 1. I., GRANT, W. S., KIRBY, R. AND ROBB, F. T. 1988. Evolutionary divergence between sympatric species of southern African Hakes, Merluccius capensis and M. paradoxus. II. Restriction enzyme analysis of mitochondrial DNA. Heredity, 61, 21-30.

BEIRNE, B. P. 1972. Pest insects of annual crop plants in Canada. Part V. Orthoptera. Memoirs of the Ent. Soc. Canada, No. 85, pp. 57.

BOYCE, T. M., ZWICK, M. E. AND AQUADRO, C. F, 1989. Mitochondrial DNA in the bark weevils: Size, structure and heteroplasmy. Genetics, 123, 825-836.

BROOKS, A. R. 1958. Acridoidea of Southern Alberta, Saskatchewan and Manitoba (Orthoptera). Can. Ent. Suppl., 9, 1-92.

CHANG, H., WANG, D. AND AYALA, F, J. 1989. Mitochondrial DNA evolution in the Drosophila nasuta subgroup of species. $J$. Mol. Evol., 28, 337-348.

CHAPCO, w. 1987. Genetic variation in three subspecies of Melanoplus sanguinipes (F.). I. Morphometric traits. Genome, 29, 793-801.

CHAPCO, w. 1989. Comparative variation at four enzyme loci in ten Melanopline grasshoppers. Experientia, 45, 196-198.

CHAPCO, w. 1991. Hybridization studies in the migratory grasshopper Melanoplus sanguinipes (F.) (Acrididae). Can. Ent., 123, 417-423.

CHAPCO, W. AND BIDOCHKA, M. J. 1986. Genetic variation in prairie populations of Melanoplus sanguinipes, the migratory grasshopper. Heredity, 56, 397-408.

CHAPCO, W., BIDOCHKA, M. J. AND HODSON, F. R. H. 1987. Further genetic studies of Melanoplus sanguinipes (F.) populations. In: Baccetti, B. (ed.) Evolutionary Biology of Orthopteroid Insects, Ellis Horwood, Chichester, pp. 177-183.

COCKBURN, A. F., MiTCHELl, S. E. AND SEAWRIGHT, J. A. 1990. Cloning of the mitochondrial genome of Anopheles quadrimaculatus. Arch. Insect Biochem. Physiol., 14, 31-36.

DESAlle, R., GidDingS, L. v. AND Templeton, A. R. 1986. Mitochondrial DNA variability in natural populations of Hawaiian Drosophila. I. Methods and levels of variability 
in $D$. silvestris and D. heteroneura populations. Heredity, 56, 75-85.

ENDLER, J. A. 1977. Geographic Variation, Speciation, and Clines. Princeton University Press, Princeton, New Jersey.

EXCOFFIER, L. 1990. Evolution of human mitochondrial DNA: Evidence for departure from a pure neutral model of populations at equilibrium. J. Mol. Biol., 30, 125-139.

FEINBERG, A. P. AND VOGLESTEIN, B. 1983. A technique for radiolabeling DNA restriction endonuclease fragments to high specific activity. Anal. Biochem., 132, 6-13.

FEINBERG, A. P. AND VOGELSTEIN, B. 1984. High specific activity labelling of DNA restriction endonuclease fragments: Addendum Anal. Biochem., 137, 266.

FELSENSTEIN, J. 1988. PHYLIP (Phylogeny Inference Package) Version 3.1 Manual., Seattle, Washington.

GONZALEZ, A. M., HERNANDEZ, M., VOLZ, A., PESTANO, J., LARRUGA, J. M., SPERLICH, D. AND CABRERA, V. M. 1990. Mitochondrial DNA evolution in the obscura species subgroup of Drosophila. J. Mol. Biol., 31, 122-131.

GURNEY, A. B. AND BROOKS, A. R. 1959. Grasshoppers of the Mexicanus group, Genus Melanoplus (Orthoptera: Acrididae). Proc. US. Natl. Mus., 110, 1-93.

HALE, L. R. AND SINGH, R. S. 1987. Mitochondrial DNA variation and genetic structure in populations of Drosophila melanogaster. Mol. Biol. Evol., 4, 622-637.

HALL, H. G. AND MURALIDHARAN, K. 1989. Evidence from mitochondrial DNA that African honey bees spread as continuous maternal lineages. Nature, 339, 211-213.

HARRIS, L. 1987. Grasshopper control in Saskatchewan. An overview from an extension worker's perspective. In: Grasshopper Workers' Conference Proceedings (Abstract). Annual Meeting of the Entomological Society of America, Boston.

HARRISON, R. G. 1989. Animal mitochondrial DNA as a genetic marker in population and evolutionary biology. Trends Ecol. Evol., 4, 6-11.

HARRISON, R. G., RAND, D. M. AND WHEELER, W. C. 1985. Mitochondrial DNA size variation within individual crickets. Science, 228, 1446-1448.

KAMBHAMPATI, S. AND RA1, K. S. 1991. Mitochondrial DNA variation within and among populations of the mosquito Aedes albopictus. Genome, 34, 288-292.

MANIATIS, T., FRITSCH, E. F. AND SAMBROOK, J. 1982. Molecular Cloning: A Laboratory Manual. Cold Spring Harbor Publications, Cold Spring Harbor.

MARCHANT, A. D. 1988. Apparent introgression of mitochondrial DNA across a narrow hybrid zone in the Caledia captiva species-complex. Heredity, 60, 39-46.

MARTIN, A. AND SIMON, C. 1990. Differing levels of amongpopulation divergence in the mitochondrial DNA of periodical cicadas related to historical biogeography. Evolution, 44, 1066-1080.

MCANELLY, M. L. AND RANKIN, M. A. 1986. Migration in the grasshopper Melanoplus sanguinipes (Fab.). II. Interactions between flight and reproduction. Biol. Bull., 170, 378-392.

MCCRACKEN, A., UHLENBUSCH, I. AND GELLISSEN, G. 1987. Structure of the cloned Locusta migratoria mitochondrial genome: restriction mapping and sequence of its $N D-1$
(URF-1) gene. Curr. Genet., 11, 625-630.

NEI, M. 1982. Evolution of human races at the gene level. In: Bonné-Tamir, B. (ed.) Human Genetics, Part A: The Unfolding Genome, A. Liss, New York, pp. 167-181.

NEI, M. 1987. Molecular Evolutionary Genetics. Columbia University Press, New York.

NEI, M. AND LI, W.-H. 1979. Mathematical model for studying genetic variation in terms of restriction endonucleases. Proc. Natl. Acad. Sci., U.S.A., 76, 5269-5273.

PARKER, J. R., NEWTON, R. C. AND SHOTWELL, R. L. 1955. Observations of mass flights and other activities of the migratory grasshopper. U.S. Dept. Agr. Tech. Bull., 1109, 1-46.

PFADT, R. E. 1988. Field Guide to Common Western Grasshoppers. USDA APHIS, Laramie, Wyoming.

PFADT, R. E. AND SMITH, D. S. 1972. Net reproductive rate and capacity for increase of the migratory grasshopper, Melanoplus sanguinipes (F.). Acrida, 1, 149-165.

PICKFORD, R. AND GILLOTT, C. 1972. Coupling behaviour of the migratory grasshopper, Melanoplus sanguinipes (Orthoptera: Acrididae). Can. Ent., 104, 873-879.

PICKFORD, R. AND RANDELL, R. L. 1969. A non-diapause strain of the migratory grasshopper Melanoplus sanguinipes (Orthoptera: Acrididae). Can. Ent., 101, 894-896.

POWERS, T. O., JENSEN, S. G., KINDLER, S. D., STRYKER, C. J. AND SANDALL, L. J. 1989. Mitochondrial DNA divergence among greenbug (Homoptera: Aphididae) biotypes. Ann. Entomol. Soc. Am., 82, 298-302.

RIEGERT, P. W. 1968. A history of grasshopper abundance surveys and forecasts of outbreaks in Saskatchewan. Memoirs of the Ent. Soc. Canada, No. 52, pp. 99.

ROEHRDANZ, R. L. 1990. The mitochondrial DNA (mtDNA) of the boll weevil: restriction site map, genome organization, and geographical polymorphism. Genome Abstract no. 1.156 Genetics Society of America, Annual Meeting, San Francisco.

ROEHRDANZ, R. L. AND JOHNSON, D. A. 1988. Mitochondrial DNA variation among geographical populations of the screwworm fly, Cochliomyia hominivorax. J. Med. Entomol., 25, 136-141.

RUSCHE, J. R. AND HOWARD-FLANDERS, P. 1985. Hexamine cobalt chloride promotes intermolecular ligation of blunt end DNA fragments by T4 DNA ligase. Nucl. Acids Res., 13, 1997-2008.

SCHMITZ, J. AND MORITZ, R. F. A. 1990. Mitochondrial DNA variation in social wasps (Hymenoptera, Vespidae). Experientia, 46, 1068-1072.

SMITH, R. C. 1954. An analysis of 100 years of grasshopper populations in Kansas (1854 to 1954). Trans. Kans. Acad. Sci., 57, 397-433.

SOLIGNAC, M., MONNEROT, M. AND MOUNOLOU, J.-C. 1986. Mitochondrial DNA evolution in the melanogaster species subgroup of Drosophila. J. Mol. Biol., 23, 31-40.

SOUTHERN, E. M. 1975. Detection of specific sequences among DNA fragments separated by gel electrophoresis. J. Mol. Biol., 98, 503-517.

STORER, J. 1989. Geological History of Saskatchewan. Govt. of Saskatchewan, Regina.

TAMURA, K. AND AOTSUKA, T. 1988. Rapid isolation method of animal mitochondrial DNA by the alkaline lysis proce- 
dure. Biochem. Genet, 26, 815-819.

TEMPLETON, A. R. 1983. Phylogenetic inference from restriction endonuclease cleavage site maps with particular reference to the evolution of humans and apes. Evolution, 37, 221-244.

TRICK, M. AND DOVER, G. A. 1984. Genetic relationships between subspecies of the tsetse fly Glossina morsitans inferred from variation in mitochondrial DNA sequences. Can. J. Genet. Cytol., 26, 692-697.

VICKERY, v. R. 1979. Notes on some Canadian Acrididae (Orthoptera). Can. Ent., 111,699-702.
VICKERY, v. R. 1989. The biogeography of Canadian Grylloptera and Orthoptera, Can. Ent., 121, 389-424.

VICKERY, V. R. AND KEVAN, D. K. MCE. 1983. A Monograph of the Orthopteroid Insects of Canada and Adjacent Regions. Lyman Entomol. Mus. and Res. Lab. Mernoir.. 13, $681-1462$.

WILSON, A. C., CANN. R. L., CARR, S. M., GEORGE, M., GYLLENSTEN, U. B., HELM-BYCHOWSKI, K. M., HIGUCHI, R. G., PALUMBI, S. R., PRAGER, E. M., SAGE, R. D. AND STONEKING, M. 1985. Mitochondrial DNA and two perspectives on evolutionary genetics. Biol. J. Linn. Soc., 26, 375-400. 